\title{
New insights on the rarity of the vulnerable Cinereous Warbling-finch (Aves, Emberizidae) based on density, home range, and habitat selection
}

\author{
Marques-Santos, Fi*, Wischhoff, ${ }^{a}{ }^{a}$ and Rodrigues, M. $^{a}$ \\ ${ }^{a}$ Laboratório de Ornitologia, Departamento de Zoologia, Universidade Federal de Minas Gerais - UFMG, \\ Avenida Antônio Carlos, 6627, Pampulha, CP 486, CEP 31270-901, Belo Horizonte, MG, Brazil \\ *e-mail: frankius@gmail.com
}

Received: March 19, 2013 - Accepted: August 27, 2013

(With 2 figures)

\begin{abstract}
The Cinereous Warbling-finch Poospiza cinerea (Emberizidae) is a Neotropical grassland bird considered rare, with population declining due to habitat loss and classified as vulnerable. However, the species conspicuously remains in several degraded areas, suggesting that it may be favored by these environments. Studies which focus on this species were inexistent until 2012, making questionable any statement about its threaten status. Here we analyzed population density, home range, and habitat selection of two groups of $P$. cinerea at independent sites that differ in human impact levels. Density was estimated by counting and mapping birds. Kernel density and minimum convex polygon were used to estimate home ranges. Habitat selection was inferred from use and availability of every habitat identified within the home range boundaries. One group positively selected urban tree vegetation, despite the availability of natural habitats in its home range. Based on a review on the literature and our findings, we assume that it is unlikely that $P$. cinerea is rare owing to habitat degradation, as previously thought. Nevertheless, this species was always recorded around native Cerrado vegetation and thus habitat modification may still threaten this species at some level. It is suggested that this species might be a woodland edge species, but future studies are necessary to confirm this assumption.
\end{abstract}

Keywords: rare species, Brazilian cerrados, degraded habitats, threatened species, edge effect.

\section{Esclarecimentos sobre a raridade do vulnerável capacetinho-do-oco-do-pau (Aves, Emberizidae) baseados em densidade populacional, área de vida e seleção de habitat}

\begin{abstract}
Resumo
O capacetinho-do-oco-do-pau Poospiza cinerea (Emberizidae) é um passeriforme neotropical de ambientes abertos, considerado raro e cuja população está em declínio devido à perda de habitat, sendo classificada como vulnerável. No entanto, a espécie tem sido observada com frequência em vários locais impactados, sugerindo que possa ser favorecida por esse tipo de ambiente. Estudos focados nessa espécie são escassos, o que nos leva a questionar qualquer afirmação sobre seu status de conservação. Nós analisamos a densidade populacional, área de vida e seleção de habitat de dois grupos de $P$. cinerea em dois locais independentes, que diferiam quanto ao grau de conservação. A densidade foi estimada por contagem e mapeamento das aves. Utilizamos Kernel density e Mínimo Polígono Convexo para estimar as áreas de vida. A seleção de habitat foi inferida a partir do uso e disponibilidade dos habitats nas áreas de vida. Um grupo selecionou positivamente árvores urbanas, apesar de ampla disponibilidade de vegetação natural na área de vida. Com base na revisão de literatura e também em nossas observações, consideramos improvável que a espécie seja rara devido à degradação de habitats naturais como anteriormente sugerido. Mesmo assim, a espécie sempre é observada em ambientes que contém vegetação nativa de Cerrado e, portanto, a degradação desse bioma pode ainda ser uma ameaça. É sugerido que Poospiza cinerea seja uma espécie de borda, e estudos futuros são necessários para confirmação dessa hipótese.
\end{abstract}

Palavras-chave: espécie rara, Cerrado, degradação de habitats, espécie ameaçada, efeito de borda.

\section{Introduction}

The Cinereous Warbling-finch Poospiza cinerea Bonaparte (Emberizidae) is a Neotropical grassland bird considered rare with population declining due to habitat loss (Stotz et al., 1996; Birdlife International, 2013), and thus classified as vulnerable (Birdlife International, 2013). However, new evidences suggest that $P$. cinerea 
may tolerate or even take advantage from altered areas (Birdlife International, 2013). The species was observed around woods in abandoned pastures (Simon et al., 1999; Ribon, 2002), around road edges and abandoned open-pit mines (Vasconcelos, 2007), degraded cerrado vegetation, roads, pastures and orchards (Lopes et al., 2010). Hence, Birdlife International (2013) proposes that the tolerance of the species to degraded habitats must be clarified. If this supposed tolerance is proven true, this bird could be down-listed to the least concern or near threatened statuses of global threat.

Records of this species are scarce in literature, limited to few individuals per site and isolated in time (mainly Ridgely and Tudor, 1989; Stotz et al., 1996; Simon et al., 1999; Vasconcelos et al., 1999, Ribon, 2002; Vasconcelos, 2007; Vasconcelos and D'angelo Neto, 2007; Lopes et al 2010; Rodrigues et al., 2011; Costa and Rodrigues, 2012, 2013; Wischhoff et al., 2012). In fact, $P$. cinerea is poorly known, having a large gap in its basic biology information (Wischhoff et al., 2012), also being considered as data deficient in the Brazilian red list (Machado, 2005).

Several authors claim that $P$. cinerea is rare, has natural rarity, low density (Ridgely and Tudor, 1989; Stotz et al., 1996; Lopes et al., 2009), or irregular frequency due to nomadic behavior (Melo-Júnior, 1998). Nevertheless, these statements remain unclear, since population density of $P$. cinerea has never been estimated on a systematic schedule, and to date, nomadic behavior was rejected for just one bird couple (Costa and Rodrigues, 2013). In addition, the consequences of human impact to this apparent rarity are unknown. This knowledge is necessary to find out if populations are declining (Melo-Júnior, 1998). Hence, it is desirable that habitat use and preferences, home range and population density within area of occurrences of the species are described, which are the aims of this study. Moreover, these data are important to understand several ecological processes (Wauters et al., 2005; 2007), that might clarify the reasons for its rarity, and have potential use in population conservation strategies, by revealing the species requirements (Bellis et al., 2004). Also in the future, such information might be useful to find new populations, identify factors that limit the species' distribution and predict its total range.

\section{Material and Methods}

\section{Study areas}

From May 2010 to April 2011, two researchers spent 290 hours of fieldwork on two sites in the state of Minas Gerais, southeastern Brazil. The first site includes the Paredão da Serra do Curral City Park (PSC) (S $19^{\circ} 57.724^{\prime}$ W $43^{\circ}$ 55.143', 1136-1380 $\mathrm{m}$ ) and adjacent urban and field areas, in the south of Belo Horizonte city. This Park includes several peaks from Serra do Curral, a hilly alignment in ferruginous soil (Ferreira et al., 2009) which is located in southern Espinhaço Mountain Range (Vasconcelos and Rodrigues, 2010). The climate has dry winters and rainy summers, with annual mean rainfall of $1,560 \mathrm{~mm}$. The area is dominated by savannah-like cerrado vegetation and fragments of Atlantic forest, on the ferruginous soil known as canga (Jacobi et al., 2008). The park suffers from criminal burnings, open-pit mining, urbanization, and settlement of exotic plant species (e.g., Pinus sp., Eucalyptus sp., Brachiaria sp., Melinis minutiflora). The second site, Alto da Boa Vista (ABV) (S 19 17.329' W $43^{\circ} 35.302$ ', 1.168-1.276 m), is located in the Morro da Pedreira Environmental Protection Area, which circumvents the Serra do Cipó National Park (Costa and Rodrigues, 2012). This entire complex is located inside the Espinhaço Mountain Range, in an ecotone region between the Cerrado and Atlantic forest biomes. This mountain range contains typical rocky fields vegetation (campos rupestres) in scattered quartzite outcrops, with thousands of endemic species (Giulietti et al., 1997). The annual mean rainfall is 1,500 mm (Rodrigues et al., 2011).

\section{Population density}

Once the first bird group in each study area was found, we extended the search area in all directions to find other groups, using radio-playbacks. We mist-netted and marked three birds with color and CEMAVE (Brazilian banding program) metal bands for identification on field, and then weighed with $0.1 \mathrm{~g}$ precision. With aid of a GPSr device, we mapped the groups and the areas searched. We then used the data points of sampled areas to build a polygon of sampled areas in GIS software (Quantum GIS, 2010).

\section{Home range}

Identified birds were located without playback assistance and tracked to record location points. The points were sampled at $60 \mathrm{~min}$ intervals (with tolerance of $\pm 10 \mathrm{~min}$ ), which seemed adequate in field to reach biological independence between locations (Lair, 1987; see Barg et al., 2005 for extensive discussion over sampling independence). Since flocks were aggregated and with permanent members, home ranges were calculated for groups rather than individuals. The software ArcView 3.2 was used with Home Range Extension 0.9 (Rodgers and Carr, 1998). The estimators were: (1) Kernel Density Estimator (KDE) by volume contouring of $95 \%$ (Worton, 1989) with fixed smoothing factor obtained by the least squares cross validation method (Seaman and Powell, 1996; Seaman et al., 1999); (2) Minimum Convex Polygon (MCP) with $100 \%$ of locations. The core areas of activity in KDE were calculated (Powell, 2000).

To estimate the stabilization of home range areas, we used the criteria by Laver and Kelly (2008), which determine the sufficient sample effort (bootstrapped confidence interval less than $10 \%$ of total home range for five consecutive location points). Additionally, a site fidelity test (10,000 iterations) was conducted in Animal movement software (Hooge and Eichenlaub, 2000) to verify if any shift in home range location during the study period occurred (the null model implies random movements without aggregation in space). 


\section{Habitat selection}

Johnson (1980) grades the habitat selection in four orders, from geographic range to diet composition. The second and third orders were used for analysis. The second order selection determines where the home range is located in the study area, and it was analyzed indirectly, observing the adjacent non-used areas, topography, and vegetation.

The third order selection was analyzed following a use-availability design (Garshelis, 2000). The habitat use consisted of all location points sampled; the availability, of every habitat identified inside the KDE home range boundaries. The difference among use and availability was tested using a goodness-of-fit test (Byers et al., 1984). The habitats boundaries were delineated with a GPSr, and the area was calculated using software (Quantum GIS, 2010).

By natural habitats we mean the types of the Cerrado Biome classified in Ribeiro and Walter (1998) with some modifications detailed ahead. These authors distinguish rocky cerrado and rocky fields from all other types of habitat by the substrate and by particular vegetation species, and therefore, structure and growth forms are somewhat secondary. Here, we further classified the rocky fields and the rocky cerrado using the same structure and growth form values for non-rocky cerrados and fields. This new classification best fitted the scale and variation in the study area. Additionally, the wet grasslands class and some non-natural habitats were added, which did not follow any description from literature.

\section{Results}

\section{Population density}

The total area sampled in PSC and adjacent areas was of 160 ha. Twelve birds were found, distributed in one group of four individuals (from now on, PSC group), two groups of three individuals, and one group of two individuals. The population density was $7.5 \mathrm{birds} / \mathrm{Km}^{2}$. In 63 net-hours, two birds of PSC group were captured and marked.

At ABV, the sampled area was of 75 ha. One group of three birds was found (from now on, ABV group). During 26 net-hours, one female with a protruding egg in the abdomen was captured and marked in 8 Dec. 2010. A fourth member was born during data collection, resulting in a population density of $5.34 \mathrm{birds} / \mathrm{Km}^{2}$. Body mass of captured birds, which are rare in literature for this species, were respectively of: $19.0,17.5$ and $19.5 \mathrm{~g}$.

\section{Home range}

The five $P$. cinerea groups had two to four individuals. Each group protects the territory with body display and songs, when stimulated with playback. The groups are strongly cohesive, and birds rarely stay more than $10 \mathrm{~m}$ apart from each other. The home ranges were calculated

Table 1. Home range values of Paredão da Serra do Curral City Park bird group (PSC) and Alto da Boa Vista bird group (ABV) group of Poospiza cinerea by two home range estimators: minimum convex polygon (MCP) and kernel density estimator (KDE). Sufficient sampling refers to bootstrap test to estimate the minimum location points to reach the home range area asymptote (Laver and Kelly, 2008).

\begin{tabular}{lcc}
\hline \multicolumn{1}{c}{ Bird group } & PSC & ABV \\
\hline Location points $(n)$ & 55 & 52 \\
MCP 100\% (ha) & 13.6 & 21.3 \\
KDE 95\% (ha) & 7.7 & 20.7 \\
Core area of activity (ha) & 3.6 & 9 \\
Number of core areas & 11 & 2 \\
Sufficient sampling (MCP) & 51 & 47 \\
Sufficient sampling (KDE) & 15 & 16 \\
\hline
\end{tabular}

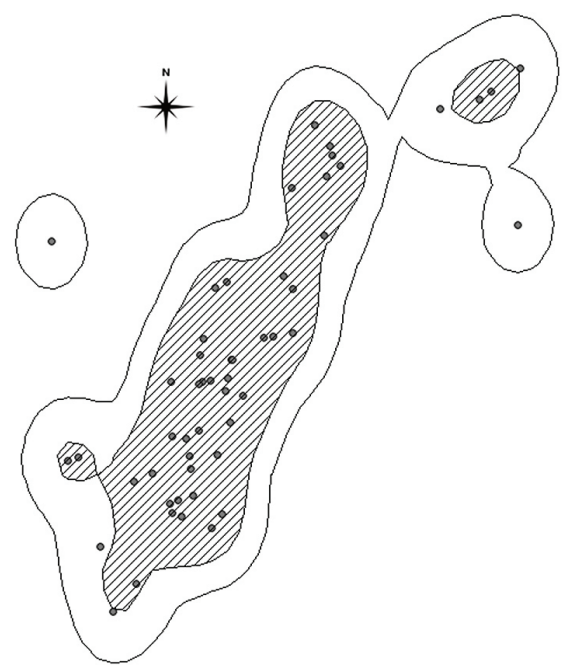

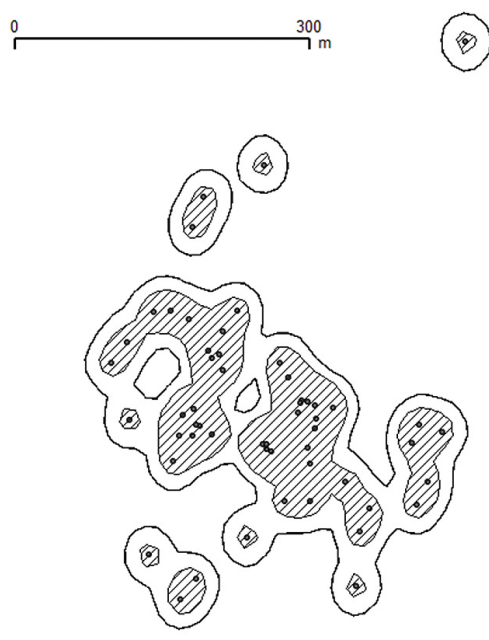

Figure 1. Home range maps of (a) Paredão da Serra do Curral City Park bird group (PSC) and (b) Alto da Boa Vista bird group (ABV) of Poospiza cinerea, Minas Gerais, Brazil. External lines contour 95\% utility distribution in KDE. Shaded regions are core areas of activity. Dots are location points. 
for PSC and ABV groups (see Figure 1 and Table 1). We never saw contact between the four groups in PSC, which can suggest little or no overlap of home ranges. The core areas of activity were equivalent to $\mathrm{KDE} 74 \%$ for PSC group and $\mathrm{KDE} 73 \%$ for $\mathrm{ABV}$ group. The ABV group had a home range area $169 \%$ larger than the PSC group by the KDE; $57 \%$ larger by the MPC estimator, and core area $150 \%$ larger. The number of cores was also different among groups. Actual sampling effort was sufficient since it surpassed the minimum sample estimate (see Table 1). The site fidelity tests indicated no shift in both home ranges locations $(p<0.001)$.

\section{Habitat selection}

In second order selection, all groups $(n=5)$ were seen using environments with steep topography, with declivity around $100 \%$. The two home ranges were located at the northwestern portion of mountain ranges. The habitat types identified and classified inside home ranges are shown in Table 2. The proportions of each habitat are in Figure 2. The PSC group's home range had high proportion of nonnatural habitats area $(62 \%)$, in contrast to the ABV group (1\%). The PSC group had higher proportion of area with medium to tall vegetation ( $14 \%$ urban trees) than the ABV group ( $1 \%$ dense rocky cerrado) and less area of natural savannic habitats (31\%) than the ABV group (54\%).

The core area of PSC had increased proportion in area of 'urban trees' and 'degraded fields with trees' and less of other habitats compared to the entire home range

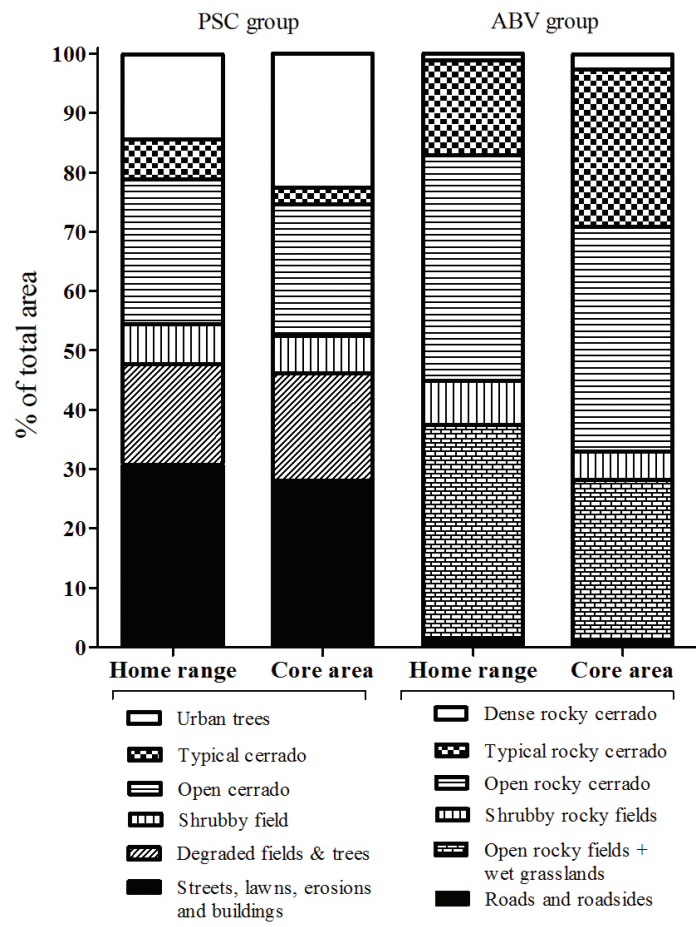

Figure 2. Area proportions of habitats inside home ranges and core areas of activity of two groups of Poospiza cinerea, one in each site in southeastern Brazil.

Table 2. Habitat types classified inside two home range areas of groups of Poospiza cinerea, Paredão da Serra do Curral City Park bird group (PSC) and Alto da Boa Vista bird group (ABV) group, each at a different site in SE Brazil. Based on Ribeiro and Walter (1998) classification, with some modifications.

\begin{tabular}{|c|c|c|c|c|}
\hline $\begin{array}{l}\text { Site or } \\
\text { Group }\end{array}$ & Habitat & $\begin{array}{l}\text { Tree cover } \\
\text { area }\end{array}$ & $\begin{array}{l}\text { Vegetation } \\
\text { cover height }\end{array}$ & Description \\
\hline \multirow[t]{6}{*}{ PSC } & Tipical cerrado & $20-50 \%$ & $3-6 \mathrm{~m}$ & Arboreal - shrubby \\
\hline & Open cerrado & $5-20 \%$ & $2-3 \mathrm{~m}$ & Arboreal - shrubby - herbaceous \\
\hline & Shrubby fields & $0-5 \%$ & - & shrubby - herbaceous \\
\hline & Urban trees & $90-100 \%$ & $4-12 \mathrm{~m}$ & $\begin{array}{l}\text { Planted or exotic trees. (e.g. Pinus sp., Casuarina } \\
\text { equisetifolia, Eucalyptus sp.) }\end{array}$ \\
\hline & $\begin{array}{l}\text { Degraded fields with } \\
\text { trees }\end{array}$ & $5 \%-20 \%$ & $2-3 \mathrm{~m}$ & $\begin{array}{l}\text { Rapid growth herbs and grasses (e.g. Brachiaria } \\
\text { sp., Melinis minutiflora) and scattered trees }\end{array}$ \\
\hline & $\begin{array}{l}\text { Streets, lawns, erosions } \\
\text { and buildings }\end{array}$ & - & - & $\begin{array}{l}\text { Presence of the Shiny Cowbird Molothrus } \\
\text { bonariensis; two storey houses with gardens }\end{array}$ \\
\hline \multirow[t]{7}{*}{$\mathrm{ABV}$} & Dense rocky cerrado & $50-70 \%$ & $5-8 \mathrm{~m}$ & Arboreal \\
\hline & Tipical rocky cerrado & $20-50 \%$ & $3-6 \mathrm{~m}$ & Arboreal - shrubby \\
\hline & Open rocky cerrado & $5-20 \%$ & $2-3 \mathrm{~m}$ & Arboreal - shrubby - herbaceous \\
\hline & Shrubby rocky fields & $0-5 \%$ & - & Shrubby - herbaceous \\
\hline & Open rocky fields & - & - & Herbaceous \\
\hline & Wet grasslands & - & - & $\begin{array}{l}\text { Poorly drained areas near watercourses. Shrubby } \\
\text { - herbaceous. Commonly Actinocephalus spp., } \\
\text { Paepalanthus spp., Araceae, Ciperaceae, Xiridaceae }\end{array}$ \\
\hline & Road and roadsides & - & - & $\begin{array}{l}\text { MG-10 state road. Uncommon vegetation in } \\
\text { contrast to all adjacent areas, which suggests } \\
\text { introduced species }\end{array}$ \\
\hline
\end{tabular}


area (see Figure 2). In the ABV group, the core area had increased proportion of 'dense rocky cerrado' and 'typical rocky cerrado' in comparison to the entire home range area.

There was significant difference among use and availability (or expected use) in both groups (PSC group: $\mathrm{c} 2=84,6 ; p<0,0001 ; \mathrm{df}=5$, ABV group: $\chi 2=32,4$; $p<0,0001 ; \mathrm{df}=5)$. Thereby, we were able to run the goodness-of-fit test, which identifies selected habitats (see Table 3). The PSC group positively selected 'urban trees' and negatively 'streets, lawns, erosions and buildings'. The ABV group positively selected 'open rocky cerrado' and negatively selected 'shrubby rocky field' and 'open rocky field with wet grasslands'.

\section{Discussion}

Three features explain species' rarity: habitat specificity, local population density, and geographical range (Rabinowitz, 1981). It has been suggested that $P$. cinerea does not have considerable niche specificity in its foraging behavior nor in its diet (Wischhoff et al., 2015). Thus, if particular habitat specificity occurs, it should happen at other scales of habitat selection or niche constraint.

Population density data is available for another finch near ABV site, the Serra Finch Embernagra longicauda Strickland. This species has population density three to four times higher than $P$. cinerea in our study (Freitas and Rodrigues, 2012). However, this is not sufficient to account $P$. cinerea as locally rare. In fact, Terborgh et al. (1990) created a classification of relative abundance for a bird community on a 97 ha plot in the Amazon Rainforest.
In that classification, $P$. cinerea would be included as uncommon (Terborgh's 1-4 pairs $/ \mathrm{Km}^{2}$ ), rather than locally rare $\left(<1\right.$ pair $\left./ \mathrm{Km}^{2}\right)$. No previous records in literature about this species have reported more birds per site than our study.

The third feature of a rare species, the geographical range, is yet to be studied. The most extensive survey about $P$. cinerea location records was done by Lopes et al. (2010). Even in that study, which deals with twelve little known or threatened grassland species, $P$. cinerea had $27 \%$ less location records than average. This may suggest that $P$. cinerea occurs in small populations scattered along a broad range, hence the so-called rarity.

Home range data of related species on the same region are available only for E. longicauda (Freitas and Rodrigues, 2012). This species has a home range six times smaller than $P$. cinerea. Since $E$. longicauda lives in couples, while $P$. cinerea in territorial groups of up to four birds, home range size may be correlated to number of birds in the group (Schoener, 1968).

The larger home range area in $\mathrm{ABV}$ in comparison to PSC group could be a result of differences in vegetation height, which could have influenced food availability. The irregular home ranges and multiple cores in PSC and ABV groups suggest that they use patches of suitable habitat, which is more visible in PSC. Terborgh et al. (1990) suggests that low density birds are also those that choose particular patches of habitat.

Our site fidelity test and field observations did not show that $P$. cinerea has semi-nomadic behavior, contradicting previous suggestion (Melo-Júnior 1998) and corroborating with another study (Costa and Rodrigues, 2013). In fact,

Table 3. Habitat selection by Paredão da Serra do Curral City Park bird group (PSC) and Alto da Boa Vista bird group (ABV) group of Poospiza cinerea in two sites in SE Brazil. This test (Byers et al., 1984) compares multiple confidence intervals of observed use to expected proportion of use of habitat.

\begin{tabular}{|c|c|c|c|c|c|c|}
\hline \multicolumn{7}{|c|}{ PSC group/site } \\
\hline Habitat & $\begin{array}{c}\text { Actual } \\
\text { proportion of }\end{array}$ & $\begin{array}{c}\text { Expected } \\
\text { proportion of }\end{array}$ & \multicolumn{3}{|c|}{ Bonferroni intervals for $P_{\mathrm{i}}$} & \multirow{2}{*}{$\begin{array}{c}\text { Selection type } \\
\text { Positive }\end{array}$} \\
\hline Urban trees & 0.564 & 0.144 & 0.387 & $\leq P_{1} \leq$ & 0.740 & \\
\hline Typical cerrado & 0.036 & 0.067 & -0.030 & $\leq P_{2} \leq$ & 0.103 & Not significant \\
\hline Open cerrado & 0.182 & 0.244 & 0.045 & $\leq P_{3} \leq$ & 0.319 & Not significant \\
\hline Shrubby field & 0.055 & 0.067 & -0.026 & $\leq P_{4} \leq$ & 0.135 & Not significant \\
\hline Degraded fields with trees & 0.145 & 0.169 & 0.020 & $\leq P_{5} \leq$ & 0.271 & Not significant \\
\hline $\begin{array}{l}\text { Streets, lawns, erosions } \\
\text { and buildings }\end{array}$ & 0.018 & 0.308 & -0.029 & $\leq P_{6} \leq$ & 0.066 & Negative \\
\hline \multicolumn{7}{|c|}{ ABV group/site } \\
\hline Dense rocky cerrado & 0.038 & 0.011 & -0.032 & $\leq P_{1} \leq$ & 0.109 & Not significant \\
\hline Typical rocky cerrado & 0.269 & 0.160 & 0.107 & $\leq P_{2} \leq$ & 0.432 & Not significant \\
\hline Open rocky cerrado & 0.615 & 0.381 & 0.437 & $\leq P_{3} \leq$ & 0.793 & Positive \\
\hline Shrubby rocky field & 0.019 & 0.074 & -0.031 & $\leq P_{4} \leq$ & 0.069 & Negative \\
\hline $\begin{array}{l}\text { Open rocky field } \\
+ \text { wet grasslands }{ }^{\mathrm{a}}\end{array}$ & 0.038 & 0.361 & -0.032 & $\leq P_{5} \leq$ & 0.109 & Negative \\
\hline Road and roadsides & 0.019 & 0.014 & -0.031 & $\leq P_{6} \leq$ & 0.069 & Not significant \\
\hline
\end{tabular}

${ }^{\mathrm{a}}$ Clustered classes in order to fulfill the requirements of distribution for the chi-square test. 
at least one individual of PSC group was still seen in the center of its home range area in the next reproductive season (Oct. 2011).

The pattern of slope use by $P$. cinerea in the second order selection was never described, although it is fairly known that it inhabits hilly areas (Simon et al., 1999; Ribon, 2002; Vasconcelos, 2007; Lopes et al., 2010). It is possible that this species best fits higher altitudes and/ or steep topography. Location records cited in this paper were in relative high altitudes for the Cerrado region, with some exceptions (Ridgely and Tudor, 1989; Stotz et al., 1996). Still, these hypotheses remain open and more data are needed.

In the third order selection, the PSC group clearly benefited from modified habitats, especially in tall vegetation (urban trees), although natural cerrado cover seemed to be important as well, with $20 \%$ of habitat use. Avoidance of urban open areas, lawns, and erosions were expected, since the species forages in vegetation cover and rarely comes down to the ground (Wischhoff et al., 2015). In the ABV group, on the other hand, the selection of tall and medium sized vegetation structure did not achieve statistical relevance. These habitats had little availability in the home range area. The open rocky cerrado vegetation was available in high proportion and was positively selected, which suggests that the cerrado vegetation is also important for this species. The roadside vegetation was used according to its availability, showing that the ABV group also forages in some degraded habitats. The higher population density in PSC site raises the idea that partially degraded habitats could benefit this species. Moreover, the PSC had smaller home range area and more core areas than the ABV group, which suggests that food in this site is more abundant, and is concentrated along more patchy woodland edges.

The Black-capped Warbling Finch Poospiza melanoleuca (d'Orbigny \& Lafresnaye) was sometimes considered the same species as $P$. cinerea (Ridgely and Tudor, 1989; Fjeldså, 1992). It is common and widespread in low woodland and shrubbery, from Andean slopes and dry intermontane valleys in Bolivia (up to $1800 \mathrm{~m}$ ), across lowlands and Chaco in Argentina, Paraguay, Uruguay, and Brazil (Ridgely and Tudor, 1989). Sometimes it is also seen in areas around houses (Di Giacomo, 2005). This broad suitability to different habitat types and altitudes in $P$. melanoleuca raises the question if this also occurs in $P$. cinerea. This could reinforce that $P$. cinerea prospers at some degraded habitats.

In summary, the evidences are as follows: (1) our analyses indicate that $P$. cinerea has some flexibility in habitat use and selection, from natural open cerrado habitats to exotic tall urban tree vegetation, while we first described its nest at a roadside at another paper (Wischhoff et al., 2012); (2) the PSC group has a patchy home range with intensive use of woodland edges; (3) the few existent records of $P$. cinerea are frequently in edges between natural and modified environments (Simon et al., 1999; Ribon, 2002; Vasconcelos, 2007; Lopes et al., 2010); (4) this species is very similar to $P$. melanoleuca, which is a common and broadly distributed species. Thus, here we suggest that it is unlikely that $P$. cinerea is scarce owing to habitat degradation, as previously put forward by Ridgely and Tudor (1989). On the other hand, all records of this bird in literature and in our study show that it inhabits sites with native cerrado vegetation in the proximity. Therefore, we highlight that if this species is rare due to factors other than human impacts, it does not mean that it is not threatened to extinction due to habitat loss. Rather, we suggest that this species is scarce due to other natural factors, like optimal altitude or optimal topography (declivity). Additionally, the outlined evidences indicate that woodland edges of native vegetation might be important for this species. In this case, $P$. cinerea could be a woodland edge species, which could explain its inconspicuousness in its geographical range, along with non-overlapping large home ranges and aggregated individuals in groups, which also can decrease the likelihood of recording this species on field. These might be responsible for its previous suggested rarity.

\section{Acknowledgements}

This work was supported by the Brazilian Research Council (CNPq). MR received fellowships from CNPq and FAPEMIG (PPM). FMS received an undergraduate scholarship from CNPq. We thank Belo Horizonte Parks Foundation and ICMBIO for permission to work in PSC City Park and Serra do Cipó. To GW. Fernandes by permitting the access to Alto da Boa Vista. We also thank MF. Vasconcelos and two anonymous reviewers for suggestions and comments.

\section{References}

BARG, JJ., JONES, J. and ROBERTSON, RJ., 2005. Describing breeding territories of migratory passerines: suggestions for sampling, choice of estimator, and delineation of core areas. Journal of Animal Ecology, vol. 74, no. 1, p. 139-149. http:// dx.doi.org/10.1111/j.1365-2656.2004.00906.x.

BELLIS, LM., MARTELLA, MB., NAVARRO, JL. and VIGNOLO, PE., 2004. Home range of greater and lesser rhea in Argentina: relevance to conservation. Biodiversity and Conservation, vol. 13, no. 14, p. 2589-2598. http://dx.doi.org/10.1007/s10531-004-1086-0.

BIRDLIFE INTERNATIONAL, 2013. Species factsheet: Poospiza cinerea. Available from: $<\mathrm{http}: / / \mathrm{www}$.birdlife.org $>$. Access in: Aug. 2013.

BYERS, CR., STEINHORST, RK. and KRAUSMAN, PR., 1984. Clarification of a technique for analysis of utilization-availability data. The Journal of Wildlife Management, vol. 48, no. 3, p. 1050-1053. http://dx.doi.org/10.2307/3801467.

COSTA, LM. and RODRIGUES, M., 2012. Bird community structure and dynamics in the campos rupestres of southern Espinhaço Range, Brazil: diversity, phenology and conservation. Revista Brasileira de Ornitologia, vol. 20, no. 2, p. 132-147.

COSTA, LM. and RODRIGUES, M., 2013. Notes on residency, home range and natural history of the 'Vulnerable' Cinereous Warbling-Finch Poospiza cinerea. The Wilson Journal of Ornithology, vol. 125 , no. 2, p. 433-438. http://dx.doi.org/10.1676/12-115.1. 
DI GIACOMO, AG., 2005. Aves de la Reserva El Bagual. In DI GIACOMO, AG. and KRAPOVICKAS, SF. (Eds.). Historia natural y paisaje de la Reserva El Bagual, Provincia de Formosa, Argentina. Inventario de la fauna de vertebrados y de la flora vascular de un área protegida del Chaco Húmedo. Buenos Aires: Aves Argentinas/Asociación Ornitológica del Plata. p. 201-465. Temas de Naturaleza y Conservación, vol. 4.

FERREIRA, JD., COSTA, LM. and RODRIGUES, M., 2009. Aves de um remanescente florestal do Quadrilátero Ferrífero, Minas Gerais. Biota Neotropica, vol. 9, no. 3, p. 39-54. http:// dx.doi.org/10.1590/S1676-06032009000300003.

FJELDSÅ, J., 1992. Biogeographic patterns and evolution of the avifauna of relict high-altitude woodlands of the Andes. Steenstrupia, vol. 18, no. 2, p. 9-62.

FREITAS, GHS. and RODRIGUES, M., 2012. Territory Distribution and Habitat Selection of the Serra Finch (Embernagra longicauda) in Serra Do Cipó, Brazil. The Wilson Journal of Ornithology, vol. 124, no. 1, p. 57-65. http://dx.doi.org/10.1676/10-143.1.

GARSHELIS, DL., 2000. Delusions in habitat evaluation: measuring use, selection, and importance. In BOITANI, L. and FULLER, TK. Research techniques in animal ecology: controversies and consequences. New York: Columbia University Press. p. 111-164.

GIULIETTI, AM., PIRANI, JR. and HARLEY, RM., 1997. Espinhaço Range region, eastern Brazil. In DAVIS, SD., HEYWOOD, VH., HERRERA-MACBRYDE, O., VILLA-LOBOS, J. and HAMILTON, AC. Centres of plant diversity: a guide and strategy for their conservation. Oxford: Information Press. p. 397-444.

HOOGE, PN. and EICHENLAUB, B., 2000. Animal movement extension to Arcview. Ver. 2.0. Anchorage: Alaska Science Center/ Biological Science Office/U.S. Geological Survey. Available from: $<$ http://alaska.usgs.gov/science/biology/spatial/gistools/index.php>.

JACOBI, CM., CARMO, FF. and VINCENT, RC., 2008. Estudo fitossociológico de uma comunidade vegetal sobre canga como subsídio para a reabilitação de áreas mineradas no Quadrilátero Ferrífero, MG. Revista Árvore, vol. 32, no. 2, p. 345-353. http:// dx.doi.org/10.1590/S0100-67622008000200017.

JOHNSON, DH., 1980. The comparison of usage and availability measurements for evaluating resource preference. Ecology, vol. 61, no. 1, p. 65-71. http://dx.doi.org/10.2307/1937156.

LAIR, H., 1987. Estimating the location of the focal center in red squirrel home ranges. Ecology, vol. 68, no. 4, p. 1092-1101. http://dx.doi.org/10.2307/1938381.

LAVER, PN. and KELLY, MJ., 2008. A critical review of home range studies. The Journal of Wildlife Management, vol. 72, no. 1, p. 290-298. http://dx.doi.org/10.2193/2005-589.

LOPES, LE., MALACCO, GB., ALTEFF, E., VASCONCELOS, MF., HOFFMANN, D. and SILVEIRA, LF., 2010. Range extensions and conservation of some threatened or little known Brazilian grassland birds. Bird Conservation International, vol. 20, no. 1, p. 84-94. http://dx.doi.org/10.1017/S0959270909990190.

LOPES, LE., PINHO, JB., BERNARDON, B., OLIVEIRA, FF., BERNARDON, G., FERREIRA, LP., VASCONCELOS, MF., MALDONADO-COELHO, M., NÓBREGA, PFA. and RUBIO, TC., 2009. Aves da Chapada dos Guimarães, Mato Grosso, Brasil: uma síntese histórica do conhecimento. Papéis Avulsos de Zoologia, vol. 49, p. 9-47.

MACHADO, ABM., 2005. Lista da fauna brasileira ameaçada de extinção: incluindo as listas das espécies quase ameaçadas e deficientes em dados. Belo Horizonte: Fundação Biodiversitas. 160 p.
MELO-JÚNIOR, TA., 1998. Poospiza cinerea Bonaparte, 1850. In MACHADO, ABM. Livro vermelho das espécies ameaçadas de extinção da fauna de Minas Gerais. Belo Horizonte: Fundação Biodiversitas. p. 387-389.

POWELL, RA., 2000. Animal home ranges and territories and home range estimators. In BOITANI, L. and FULLER, TK. Research techniques in animal ecology: controversies and consequences. New York: Columbia University Press. p. 65-110.

Quantum GIS, 2010.Ver. 1.6.0 copiapó. Available from: <http:// www.qgis.org $>$.

RABINOWITZ, D., 1981. Seven forms of rarity. In SYNGE, H. The biological aspects of rare plant conservation. Chichester: John Wiley \& Sons. p. 205-217.

RIBEIRO, J. and WALTER, B., 1998. Fitofisionomias do bioma Cerrado. In SANO, SM. and ALMEIDA, SP. Cerrado: ambiente e flora. Planaltina: EMBRAPA-CPAC. p. 89-166.

RIBON, R., 2002. Colonization of eastern Brazil by the Cinereous Warbling-Finch, with some comments on its natural history. In Abstracts for the Third North American Ornithological Conference, 2002. New Orleans, Louisiana.

RIDGELY, RS. and TUDOR, G., 1989. Birds of South America: The Oscine Passerines. Austin: University of Texas Press. 516 p.

RODGERS, AR. and CARR, AP., 1998. HRE: The Home Range Extension for ArcView. Ver. 0.9. Thunder Bay: Ontario Ministry of Natural Resources/Centre for Northern Forest Ecosystem Research. Available from: < http://www.blueskytelemetry.co.uk $>$. Access in: Out. 2011.

RODRIGUES, M., FREITAS, GHS., COSTA, LM., DIAS, DF., VARELA, MLM. and RODRIGUES, LC., 2011. Avifauna, Alto do Palácio, Serra do Cipó National Park, state of Minas Gerais, southeastern Brazil. Check List, vol. 7, no. 2, p. 151-161.

SCHOENER, TW., 1968. Sizes of feeding territories among birds. Ecology, vol. 49, no. 1, p. 123-141. http://dx.doi.org/10.2307/1933567.

SEAMAN, DE. and POWELL, RA., 1996. An evaluation of the accuracy of kernel density estimators for home range analysis. Ecology, vol. 77, no. 7, p. 2075-2085. http://dx.doi. org/10.2307/2265701.

SEAMAN, DE., MILLSPAUGH, JJ., KERNOHAN, BJ., BRUNDIGE, GC., RAEDEKE, KJ. and GITZEN, RA., 1999. Effects of sample size on kernel home range estimates. The Journal of Wildlife Management, vol. 63, no. 2, p. 739-747. http://dx.doi. org/10.2307/3802664.

SIMON, J., RIBON, R. and MATTOS, G., 1999. A avifauna do Parque Estadual da Serra do Brigadeiro, Minas Gerais. Revista Árvore, vol. 23, no. 1, p. 33-48.

STOTZ, DF., FITZPATRICK, JW., PARKER III, TA. and MOSKOVITS, DK., 1996. Neotropical birds: ecology and conservation. Chicago: University of Chicago Press. 502 p.

TERBORGH, J., ROBINSON, SK., PARKER III, TA., MUNN, CA. and PIERPONT, N., 1990. Structure and organization of an Amazonian forest bird community. Ecological Monographs, vol. 60, no. 2, p. 213-238. http://dx.doi.org/10.2307/1943045.

VASCONCELOS, MF., 2007. Aves observadas no Parque Paredão da Serra do Curral, Belo Horizonte, Minas Gerais, Brasil. Atualidades Ornitológicas, vol. 136, p. 6-11.

VASCONCELOS, MF. and D'ANGELO-NETO, S., 2007. Padrões de distribuição e conservação da avifauna na região central da 
Cadeia do Espinhaço e áreas adjacentes, Minas Gerais, Brasil. Cotinga, vol. 28, p. 27-44.

VASCONCELOS, MF., MALDONADO-COELHO, M. and DURÃES, R., 1999. Notas sobre algumas espécies de aves ameaçadas e pouco conhecidas da porção meridional da Cadeia do Espinhaço, Minas Gerais. Melopsittacus, vol. 2, p. 44-50.

VASCONCELOS, MF. and RODRIGUES, M., 2010. Patterns of geographic distribution and conservation of the open-habitat avifauna of southeastern Brazilian mountaintops (campos rupestres and campos de altitude). Papéis Avulsos de Zoologia, vol. 50, no. 1, p. 1-29.

WAUTERS, LA., BERTOLINO, S., ADAMO, M., VAN DONGEN, S. and TOSI, G., 2005. Food shortage disrupts social organization: the case of red squirrels in conifer forests. Evolutionary Ecology, vol. 19, no. 4, p. 375-404. http://dx.doi. org/10.1007/s10682-005-8311-5.
WAUTERS, LA., PREATONI, DG., MOLINARI, A. and TOSI, G., 2007. Radio-tracking squirrels: performance of home range density and linkage estimators with small range and sample size. Ecological Modelling, vol. 202, no. 3-4, p. 333-344. http://dx.doi. org/10.1016/j.ecolmodel.2006.11.001

WISCHHOFF, U., MARQUES-SANTOS, F. and RODRIGUES, M., 2012. Nesting of the Cinereous Warbling Finch (Poospiza cinerea) in Southeastern Brazil. The Wilson Journal of Ornithology, vol. 124, no. 1, p. 166-169. http://dx.doi.org/10.1676/11-004.1.

WISCHHOFF, U., MARQUES-SANTOS, F. and RODRIGUES, M., 2015. Foraging behavior and diet of the vulnerable Cinereous Warbling-finch Poospiza cinerea (Aves, Emberizidae). Brazilian Journal of Biology, vol. 74, no. 4, (In press)

WORTON, BJ., 1989. Kernel methods for estimating the utilization distribution in home-range studies. Ecology, vol. 70, no. 1, p. 164-168. http://dx.doi.org/10.2307/1938423. 